\title{
The Study of the Principles of Philosophy of Islamic Art
}

\author{
Hasti Safavi \\ University of Exeter \\ Stocker Road, Exeter, United Kingdom, EX4 4PY
}

\begin{abstract}
The main discourse on Islamic art in the western academia primarily views Islamic art through the lens of art history and sociology of art. Islamic art is considered as sacred in Islamic civilisation and culture, and derives its sanctity from the Quran as the fountain from which it has emanated, which Muslims consider to be the Word of God, much like Christ is the Word of God in Christianity. The Quran has played a formative role in shaping the trinity of sacred Islamic art which is Quranic recitation, calligraphy and architecture. However, another approach which not only is viable but can be considered of great importance to the study of Islamic art, is the employment and utilisation of principles of Islamic philosophy and Sufism which were the pillars of the intellectual milieu in which a given work of art is produced. The application of such principles allows a more comprehensive and detailed interpretation of a work of art. In this paper, the primary Islamic philosophy and sufi doctrines that will be discussed are the concepts of imagination, colour, and calligraphy and examples of their application in the khānqāh and shrine ensemble of Shaykh Șafi al-Din Ardabīlī in Ardabil, Iran.

Keywords: Islamic art, philosophy, Sufism, Quran, imagination, colour, calligraphy, Shaykh Șafi al-Din Ardabīlī’s shrine ensemble
\end{abstract}

\section{Article history:}

The article was submitted on 03.10.2019

The article was accepted on 06.11.2020

For citation: Hasti Safavi. The Study of the Principles of Philosophy of Islamic Art. RUDN Journal of Philosophy. 2020; 24 (1): 23-38. DOI: 10.22363/2313-2302-2020-24-1-23-38

\section{Introduction}

Any given work of art is the product of the socio-politico-cultural and intellectual aspects of the environment in which it was produced. The majority of the published research in Western academia on Islamic art has been performed through the lens of art history and sociology of art, such as the works done by O Grabar,

(C) Hasti Safavi, 2019

This work is licensed under a Creative Commons Attribution 4.0 International License https://creativecommons.org/licenses/by/4.0/ 
R Ettinghausen, and AU Pope. Another approach, which is both necessary and of great importance to the study of Islamic art, is the employment and utilisation of principles of Islamic philosophy and Sufism, the pillars of the intellectual milieu in which a given work of art is produced. Contemporary scholars, including Titus Burckhardt, Martin Lings, Annemarie Schimmel, and Seyyed Hossein Nasr, have written extensively on the philosophy of Islamic art and its importance for a comprehensive understanding of Islamic art. They are, however, criticised as their academic expertise is Islamic philosophy and Sufism, and not Islamic art and art history. The author of this paper being an art historian herself, with nine years of field studies in Iran, Turkey, Egypt, and Andalusia, aims to illustrate the importance and necessity of the application and utilisation of principles of Islamic philosophy and Sufism for a comprehensive interpretation and understanding of Islamic art. Through the utilisation of such principles, the qualitative and conceptual dimensions of a work of art can be understood and analysed. In this paper, the primary Islamic philosophy and sufi doctrines that will be discussed are the commentaries and interpretations of major Islamic philosophers and sufis of $10^{\text {th }}-14^{\text {th }}$ century CE. The concepts discussed are imagination, colour, and calligraphy; and examples of their application in the khānqāh and shrine ensemble of Shaykh Șafi al-Din Ardabīli in Ardabil, Iran. This paper will argue that for a thorough understanding of any given works of Islamic art, it is necessary to view both the socio-politico-cultural environment from which the given work had risen, as well as the application of the Islamic Philosophy and Sufism principles.

\section{Imagination}

Imagination plays a vital role in any given art, and it has been one of the major topics of Islamic philosophy and Sufism, within the history of Islamic philosophy, from the time of the founder of Islamic philosophy, al-Fārābi $\left(10^{\text {th }}\right.$ century CE) till now. Islamic philosophy and Sufism analyse the intellectual foundation of the arts with regards to the degrees of the world of imagination, as well as clarifying the connection and relationship between art, existence, and knowledge. Art and the active imagination have an intrinsic relationship; this is the most important aspect of art and gives birth to a masterpiece. The connection between the imagination faculty and the imaginal world creates the means for interpretation of the original concepts behind visual forms of art, such as the concept of light referring to the 'Light of the Lights' (verse 35 of Chapter 24, al-Nür) or 'Absolute Real Light', which means God.

The imaginal world and the faculty of imagination have been much debated amongst Muslim philosophers and mystics. Whilst the Peripatetic (Masha $\vec{\imath})$ philosophers, such as Ibn Sinā, do not believe in the existence of an independently existing imaginal world [1. P. 39 - 40], philosophers of the school of Illumination (Ishrāq $\bar{l}$ ), founded by Suhrawardī, and the Transcendental school of philosophy (al-Hikmat-i al-Muta'aliyah), founded by Mullā Șadrā, not only argue for the 
existence of the imaginal world, but see its existence as necessary for comprehension between the material world and the world of intellect.

Suhrawardī, $12^{\text {th }}$ century CE Islamic philosopher, not only argues for the existence of the worlds of intellect, souls, and matters, which is also agreed by Peripatetic philosophers, but he also argues for the existence of another world, referred to as the imaginal world or the world of ideas. Furthermore, Suhrawardi considers it necessary for the proof of many religious theories, such as purgatory, and physical resurrection. Suhrawardī is of the opinion that in Islamic ontology, passage from the sensual world to the intellectual world is an impossibility without an intermediary, thus, there must be a world that exists between the two, and has the characteristics of both. The school of Illumination refer to this world as the imaginal world. In addition, Suhrawardī is of the opinion that in Islamic epistemology other than there being a sensual faculty and intellectual faculties, there is the faculty of imagination, placed in between the other two. Thus, Suhrawardī believes that imaginal forms exist independently outside the world of the soul. These forms exist in neither the world of intellect nor the physical world, but exist in the imaginal world, which is distinctly separate from those two [2. P. 450].

Qayșarī, in the introduction of Fusūs al-Hikam by Ibn 'Arabī, has described the imaginal world as being a "spiritual world with an essence of light, and what it has in common with the essence of the body, or the physical aspects is that both can receive and measure, as well as being similar in terms of its luminosity or light with the abstract intellectual essence." [3. P. 22] Ibn Arabi, $12^{\text {th }}$ century CE Islamic philosopher and sufi, agrees with Suhrawardī's opinion on Islamic ontology, and believes that the imaginal world is the connector and intermediary of the world of nature, which is the lowest world, and the abstract world, which is the highest world. The two are also in agreement regarding Islamic epistemology. Ibn Arabi believes that imagination is an intermediary between the abstract intellect and the physical body in the lower world and exists independently in both worlds.

Ibn Arabi is of the opinion that the faculty of imagination can comprehend both those matters that have a form, and give form or dimensions to matters that do not have a form. Whilst Peripatetic philosophers believe that the world of intellect, (which as mentioned before, they do not regards as an independent existence), is a vault for all sensual forms that have been seen by the senses, and as such, stored in this vault. Ibn Arabi, in complete disagreement, not only denies that the imaginal is not a vault for the forms of the sensual world, but it is a world in which abstract forms from the absolute world of ideas have been reflected [4. P. 89].

The sensual faculties, the faculty of imagination and creativity are three of the elements that must be discussed in relation to both an artist and a work of art. By applying Ibn Arabi and Suhrawardī's ideas in regards to imagination from both an Islamic ontological and epistemological perspectives, we can see that an artist uses his/her imaginal faculty to comprehend the abstract realities from the abstract world, and, using creativity, give them a sensual form in the sensual world. When we look at the position of calligraphy in Islamic art and architecture or the 
importance of geometry, utilising abstract forms derived from the imaginal world, both are used by the artist to create a sacred space.

Islamic art aims to be a manifestation and representation of the sacred. Ibn Arabi and Suhrawardī argue, from an Islamic ontological and epistemological perspective, that the imaginal world lies between the sensual world and the world of intellect. They also argue that the faculty of imagination lies between the sensual and intellectual faculty. Hence, to gain access to the higher world and the sacred realm, the artist must first utilise his imaginal faculty, without which, the artist cannot comprehend the sacred and realities of the world of intellect. Therefore, it is essential for the artist to train and develop their imaginal faculty. However, it is important to note that it is creativity that distinguishes an artist with a powerful imaginal faculty from an artists without one imaginal faculty. Through both the mastery of technique and the brilliance of creativity, the artist can give form to the comprehensions of the imaginal faculty of the world of ideas.

The Great Mosque of Damascus (705-715 CE) is one of the most important visual representation of heaven in Islamic art and architecture. The mosaics covering the wall of the western portico depict a flow of river and tall tree surrounding small architectural buildings, each stylistically different from the other. An interpretation of these mosaics suggest that they depict heaven, or city of God, and exclude the depiction of living beings [5. P. 26]. It is also one of the best examples of in early Islamic art. In creating its mosaics art form, the artist, comprehends the reality of heaven in the abstract world and manifests it into a sensual form using both the verses of Quran and his imaginal faculty to see.

The precise mathematical formulas and ratios used in Islamic calligraphy, and the many different forms that it takes, are a result of the artists first comprehending the meaning of the words. The artist uses his imagination to connect the faculty of sense to the faculty of intellect. Then, combining the world of intellect and the imaginal world, he comprehends the true meaning of the written word, bestowing a befitting sacred visual form to the words inscribed.

Another unique aspect of Islamic art is that not only does the faculty of imagination play an important role in it, but it forces the audience to use their faculty of imagination to comprehend the reality of the work of art. Thus, the work of art becomes a sign of God, for it is a visual and comprehensible representation of the forms and ideas of the worlds of ideas presented in the sensual world, and acts as a gateway to the realities of that world. Furthermore, as the artist has used their imaginal faculty to represent realities, some of which are veiled from the world of ideas, multiple layers of meaning exist in any given work of art. Hence, the degree to which one comprehends the work depends on the power and development of the viewer's imaginal faculty of the viewer, just as the artist's validity and depth of understanding of faculty of imagination impacts what has been represented.

An example of the employment of the faculty of imagination is in the khānqāh and shrine ensemble of Shaykh Safi al-Din Ardabilin is the depiction of forty bird 
motifs on the ceiling of the ground-floor middle alcoves of the Dār al-Huffāz. which was redecorated during Shah Abbas time in $1611 \mathrm{CE}$ (figure 1).

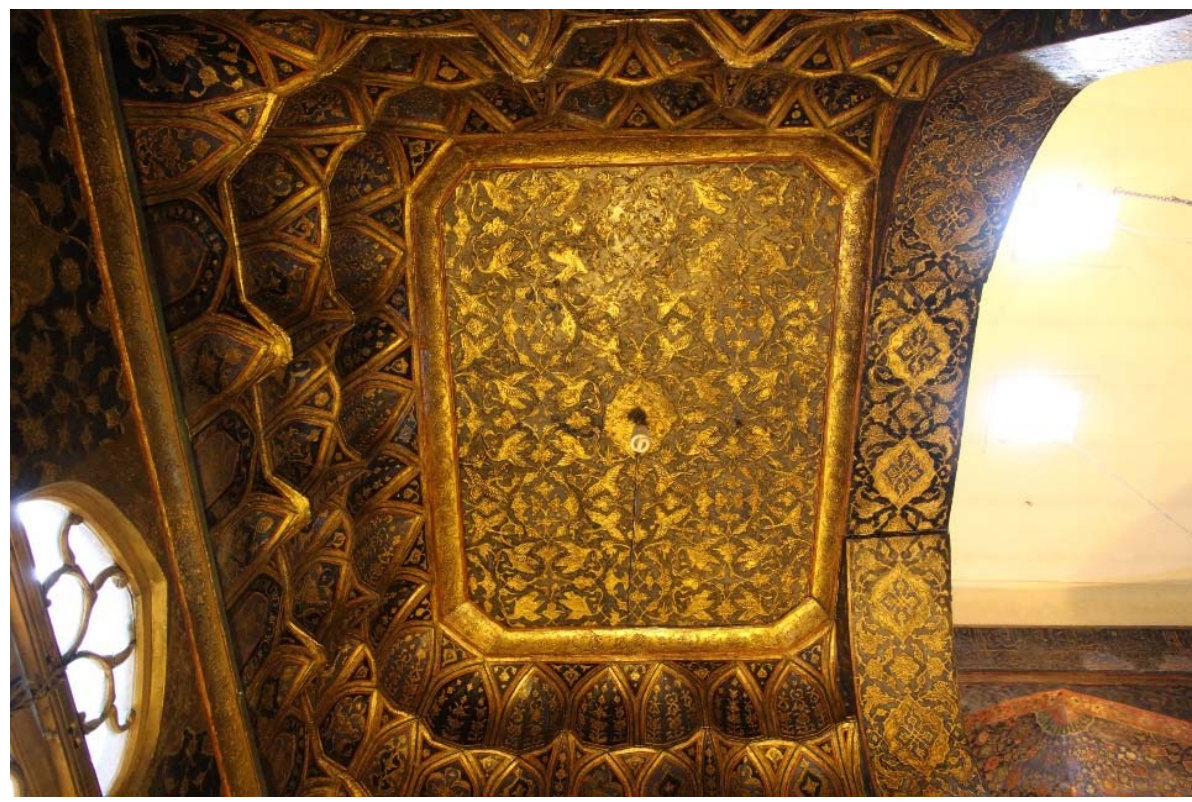

Figure 1. Forty bird motifs decorating the ground-floor middle alcoves of Dār al-Ḥuffāz Shaykh Ṣafi al-Din Ardabīlī’s khānqāh and shrine ensemble — Ardabil, Iran ${ }^{1}$

The bird shaped motifs are similar to the mythical simorq, which holds a special place in Persian literature. This symbol is further accentuated through the inscription of verse 75 of Chapter 39, Al-Zumar, in gold thuluth calligraphy, on an ultramarine background; "And thou shalt see the angels encircling all around the Throne, hymning the praise of their Lord. Judgement shall be made between them in truth, and it will be said, "Praise be to God, Lord of the world."'[6. 39: 75]. Simorq has been mentioned in great works of literature, such as Suhrewardī, Ghazālī, and 'Ațtāar's Conference of the Birds. "Here, in these works, Sìmorq is no longer merely a symbol of wisdom and peace, but it is also a representative of the Perfect Human and Eternity in Islamic Sufism. One must also note that in 'Atțār's Conference of the Birds, Simorq can also refer to Allah, as the spiritual seeker travels from his soul to Allah's Divine Attributes. The first time Simorq makes an appearance in the Conference of Birds, it is the hoopoe that tells the bird assembly of Him:

We have a king; beyond Kaf's mountain peak

The Simorgh lives, the sovereign whom you seek,

And $\mathrm{He}$ is always near to us, though we

Live far from His transcendent majesty.

A hundred thousand veils of dark and light

Withdraw His presence from our mortal sight,

\footnotetext{
${ }^{1}$ Photographer: Hasti Safavi, Copyright (c) Hasti Safavi
} 
And in both worlds no being shares the throne

That marks the Simorgh's power and His alone -

He reigns in undisturbed omnipotence,

Bathed in the light of His magnificence --

No mind, no intellect can penetrate

The mystery of his unending state:

How many countless hundred thousands pray

For patience and true knowledge of the Way

That leads to Him whom reason cannot claim,

Nor mortal purity describe or name;

There soul and mind bewildered miss the mark

And, faced by Him, like dazzled eyes, are dark -

No sage could understand His perfect grace,

Nor seer discern the beauty of His face.” [7. P. 51-52]

As such, Imagination, which is comprised of the imaginative faculty and the imaginal world, in conjunction with creativity and talent, plays a central role in the creation and production of art. Imagination is of unique importance in Islamic art and architecture as it allows the artist to manifest the sacred within the profane world, and convey realities discovered in the imaginal world in their work of art. Imagination facilitates the artist's use of symbolism and methods related to symbolism, such as light, proportion and geometry, and colour, to convey the divine within the work of art.

\section{Colour}

Light and colour, which form the foundation of visual perception, play a central role in art and architecture. In the Quran, two separate terms are used for colour in relation to nature and colour in relation to God. This forms the basis of Muslim philosophers and sufis' perception of colour. Every Sufi views and interprets colour in a distinct way. For example, Najmuddīn Kubrā, $13^{\text {th }}$ century CE sufi, views the colour white as the colour of Islam [8. P. 67], whilst Najmuddīn Rāzī, $13^{\text {th }}$ century CE sufi, interprets it as a symbol of purification of the soul [9. P. 306], and 'Alä' al-Dawla Simnānī, $14^{\text {th }}$ century CE sufi, as symbolising a secret aspect of Divine knowledge [10. P. 233]. The colour white has also been employed in the shrine ensemble of Shaykh Safi al-Din Ardabīlì, an example being the white thuluth Quranic calligraphic inscription (verses 162-163 of Chapter 10, al-Yūnus), decorating the portal door (Qibla Qapūsi) of Allah Allah Dome. These verses deal with the purification of the soul and Divine Knowledge, in keeping with the Najmuddīn Rāzī and 'Alā' al-Dawla Simnānī’s interpretation.

Light is the source of all colours, with each wavelength being a particular colour. As such, colour plays an important role in art, as it has both an aesthetic purpose and a metaphorical one for various degrees of reality and truth. A number of sufis, including Najmuddīn Kubrā, Rumi, Najmuddīn Rāzī, 'Alā' al-Dawla Simnānī, and Rumi, have written extensively on the significance and meaning of colour. In the

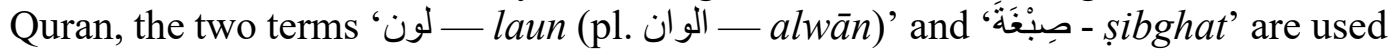




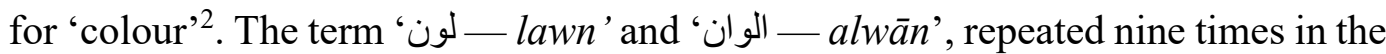
Quran, is in reference to the multitude of colours found in nature. The second term ' - sibghat', in contrast, used only twice in one verse in the Quran, is in reference to the Colour of God. In verse 138, Chapter 2, al-Baqarah, the term ص صِبْغَةَ's sibghat' is used, stating;

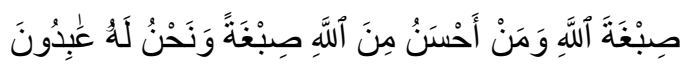

(We take our) colour from Allah, and who is better than Allah at colouring. We are His worshippers [11.2:138].

The term ' كـ - sibghat', used in this verse, refers to the Absolute Colour of God, which includes unity, peace, love, and purity, rather than race, gender, sect, and class [12].

An example of the term 'الوان' being used is in verse 27 of Chapter 35, Fâtirir;

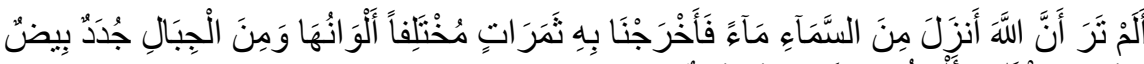

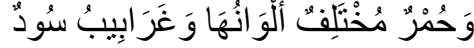

Hast thou not considered that God sends down water from the sky, wherewith We bring forth fruits of diverse colors? And in the mountain are streaks of white and red, of diverse hues, and others pitch-black [6. 35:27].

Qushayrī, $12^{\text {th }}$ century CE Muslim scholar, interpreting this verse, argues that the reference to colours in this verse illustrates the purposeful craftsmanship of God in sending rain from the skies, which, not only validates His existence but also demonstrates the Absolute Knowledge of the One [13. P. 614]. In verse 31, Chapter 18, al-Kahf, life after death is described using various colours;

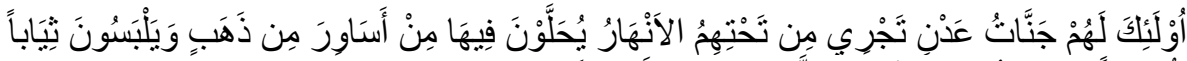

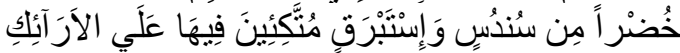

Therein they shall be adorned with bracelets of Gold, and shall wear green garments of fine silk and rich brocade, reclining upon couches [6. 18:31].

One of Najmuddīn Kubrā's main sufi doctrines was based on the concept of light and colour; this was a consequence of his spiritual journey. He combines the notion of coloured light, with the various stages or states of a sufi's spiritual journey. In Najmuddīn Kubrā's school of thought of, the aim of a sufi's journey is to attain a connection with the Almighty. God is the Light of the Lights, and a sufi, through the ascending arc after the descending arc, becomes the manifestation of God's Light. Through his journey, a sufi observes various colours, which are neither accidental in nature nor of the material world, but are reflective of the difference Attributes and Essence of God. Corbin further explains Najmuddīn Kubrā's interpretation of colour as having an "affinity and correspondence between physical

\footnotetext{
${ }^{2}$ There is debate on the meaning of the term ' ص صِنْغَغ - sibghat', as some scholars such as Sarwar, Shakir, translate it as baptism, referring to verse 135, were the creed of Ibrahim is mentioned. Others such as Pickthall interpret it as colour.
} 
colours and auric (or aural, "auroral") colours, in the sense that physical colours themselves have a moral and spiritual quality and that what the aura corresponds to it, "symbolizes with it"." [14. P. 72]

Kubrā categorises a sufi's spiritual journey into seven stages, with each stage having a specific colour, which is reflective of his spiritual state. The colours are comprised of white, yellow, green, red, dark purple, and black, with each having an esoteric meaning: white refers to Islam, yellow is the colour of faith and conscience, green the colour of identifying and ultimate belief, red the colour of mysticism and knowledge, purple the colour of emotions and presents, and black is the colour of bewilderment and ecstasy [8. P. 67-77].

Kubrā categorises the soul into three levels or layers: 1 - the nafs-i ammärih or 'carnal soul'3, which is dark and resembles a dark black circle of bitumen, 2 - the nafs-i lawwamih or 'self-reproaching soul'4, which is the same as partial reason and is red in colour, and 3- the nafs-i mutma' innah or 'peaceful soul', which is the same as a smooth polished mirror in which all lights are observed and is white in colour [8. P. 37].

Najmuddīn Rāzī, $13^{\text {th }}$ century CE sufi, a disciple of Najmuddīn Kubrā, and 'Alā' al-Dawla Simnānī, $14^{\text {th }}$ century CE sufi, who was influenced by the teachings of Najmuddīn Kubrā, have both written on the concept of colour and light, and their relation with the various stages or states of a Sufi's spiritual journey. Rāzì viewed colours as being symbolic of the soul and spiritual attributes of a wayfarer. He argues that a Sufi sees one specific colour, in each stage or state of his/her journey, which is representative of that specific state. Furthermore, he gives the three colours of black or deep purple, red, and white to the three levels of the soul, the carnal soul, the self-reproaching soul, and the peaceful soul. "The colour deep purple is seen in the state of nafs-i lawwämmah or 'self-reproaching soul', which is symbolic of the combination of the spirit and the darkness of the soul. After the development of the 'self-reproaching soul', the colour red is seen, after which as the light of the spirit dominates the soul, the colour yellow is seen. As the darkness of the soul is gradually destroyed, the colour white is seen; furthermore, the colour green is seen, as the light of the spirit is combined with the purification of heart. Finally, as the heart is purified, a light similar to that of that sun is seen." [9. P. 306]

'Alā' al-Dawla Simnānī's analysed the mystical principles of colour. These principles are divided into seven stages, with each stage symbolising a state of a Sufi's spiritual journey and colour. He has named these stages as 'latifa ghalibiya', 'latifa nafsiya', 'latifa ghalbiya', 'latiifa serriya', 'latifa ruhiya', 'latifa khafiya', and 'latifa haghiya' or 'latifa muhammadìy', which are black, blue, brownish-red, white, yellow, grey black, and green, respectively [10. P. 229-233].

Rumi, $13^{\text {th }}$ century CE sufi, refers to colours in Mathnawi, and uses them symbolically to illustrate various points. In volume one of Mathnawi, in the story of 'Further setting forth the stratagem of the hare', Rumi writes;

\footnotetext{
${ }^{3}$ It is the soul which disobeys God and commands to God.

${ }^{4}$ It is the soul which blames itself.

${ }^{5}$ It is the soul which is at peace with God.
} 
How wilt thou see red and green and russet, unless before (seeing) these three (colours) thou see the light? But since thy mind was lost (absorbed) in (perception of) the colour, those colours became to thee a veil from (debarred thee from contemplating) the light. In as much at night those colours were hidden, thou sawest that thy vision of the colour was (derived) from the light. there is no vision of colour without the external light: even so it is with the colour of inward phantasy. This outward (light) is (derived) from the sun and from Suhá, while the inward (light) is from the reflexion of the beams of (Divine) Glory [15. P. 63].

In the above mentioned verses, Rumi argues one would be able to see different colours, without being aware and receptive of light, as colour is not essential by itself but is only the shadow of light. Therefore, colour and light are connected to one another, as light is both colourless and manifested through different colours. Colour is a type of quiddity, which enters reality by different degrees of being [16. P. 45], and Rumi argues that if we only pay attention to the appearance of colour, we will be blind to the cause of colour, which is light.

Discussing the relation between being able to see relative beauty and Absolute Beauty, Martin Lings argues that if you are able to use your inner eye, you can get a glimpse of the Absolute Beauty, the source of all colours and beauty, and, subsequently, the Eternal Origin of that experience, in which caused you to see the Absolute Beauty, will also be revealed to you [17. P. 38 - 39].

The khānqāh and shrine ensemble of Shaykh Șafi al-Din Ardabīlī is an example of an Islamic monument, in this case a mosque, in which the deployment of light and colour in relation to decorative motifs has been achieved in a beautifully intrinsic manner, creating a sacred mystical environment for the worshippers. Throughout the whole monument, an array of colours, such as blue, ultramarine, yellow, green, brown, gold, red, and white have been employed to create a mystical environment (figures 2 and 3 ).

Masjid-i Nașir al-Mulk (1876-1888 CE) in Shiraz is an example of an Islamic monument, in this case a mosque, in which the deployment of light and colour in relation to decorative motifs has been achieved in a beautifully intrinsic manner, creating a sacred mystical environment for the worshippers. The western shabistān ${ }^{6}$ of the mosque, famously known as haft dargah (seven doorways), takes its name from the seven entrances decorated with multicoloured geometric patterned glass windows of the western shabistān (figure 4). When the morning light shines through the stained glass windows, a kaleidoscope of colours is reflected onto the elaborate multicoloured tileworks, decorating the interior of the shabistān. This kaleidoscopic reflection and its delicate interplay with one another create a soulful sacred ambience, further facilitating the possible departure of the worshipper's soul from the material world to the spiritual one.

\footnotetext{
${ }^{6}$ It is a roofed enclosure, with parallel pillars and is connected from one side to the courtyard of the mosque.
} 


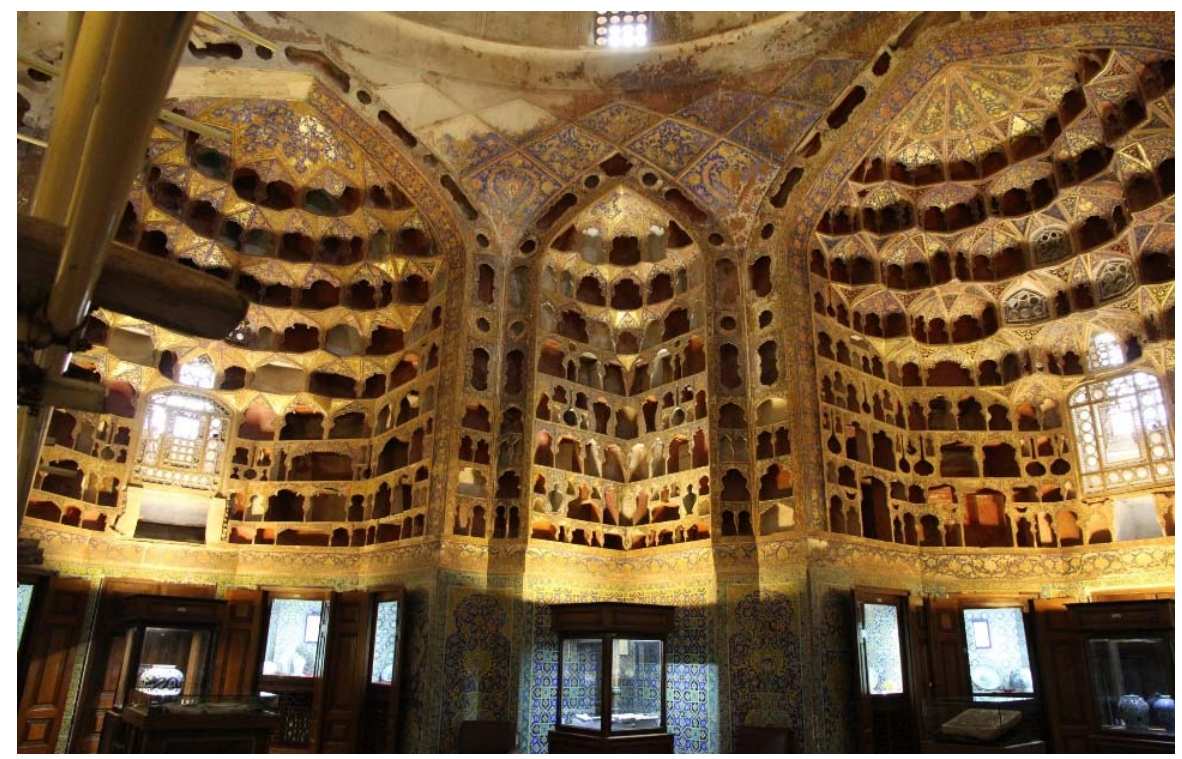

Figure 2. Chīnīkhāna of Shaykh Ṣafi al-Din Ardabīlī’s khānqāh and shrine ensemble (1301-1311, renovated in $1608 \mathrm{CE})$ - Ardabil, $\operatorname{Iran}^{7}$

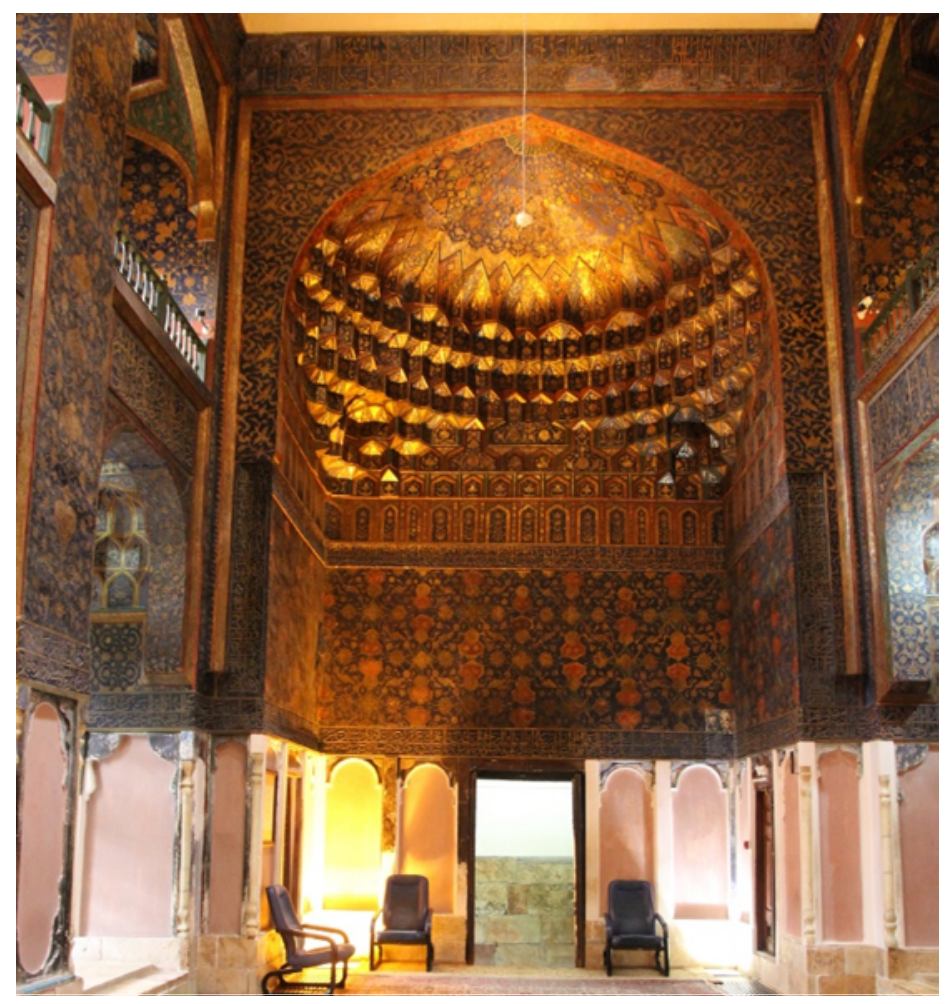

Figure 3. Northern view of Dār al-Ḥuffāz Shaykh Șafi al-Din Ardabīlī’s khānqāh and shrine ensemble - Ardabil, $\operatorname{Iran}^{8}$

\footnotetext{
${ }^{7}$ Photographer: Hasti Safavi, Copyright $@$ Hasti Safavi

${ }^{8}$ Photographer: Hasti Safavi, Copyright (c) Hasti Safavi
} 


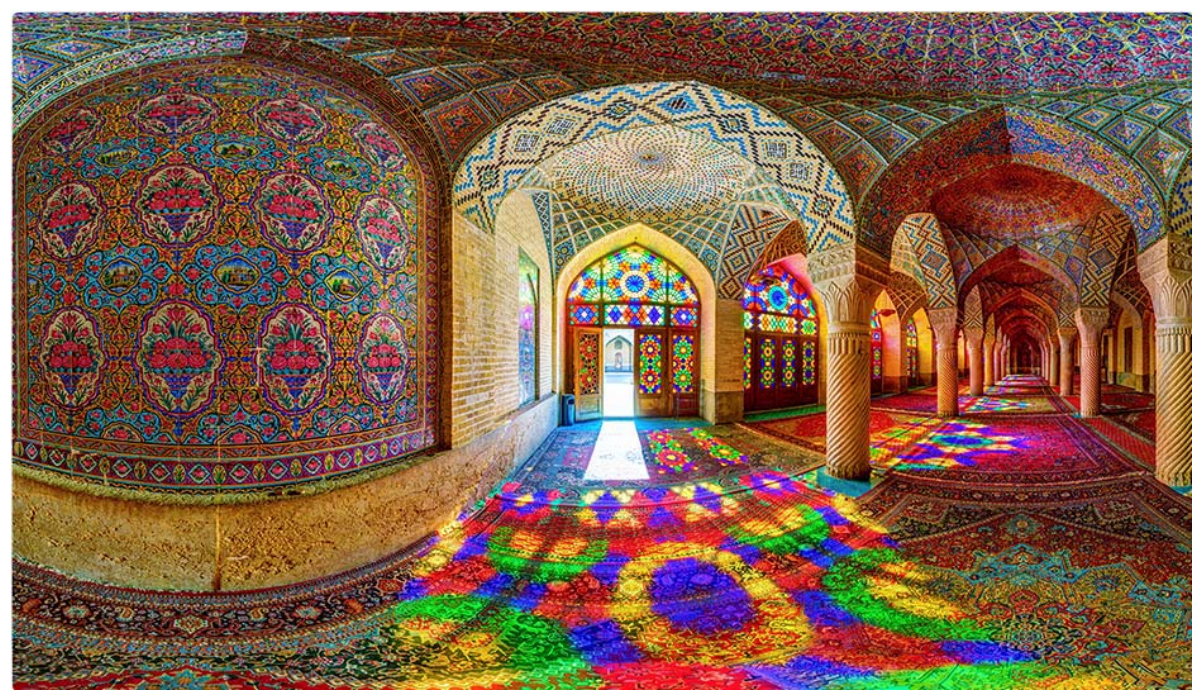

Figure 4. Western Shabistān of Masjid-i Nașir al-Mulk9

As discussed before, every colour is a different wavelength of light, hence, if we view pure and absolute light as representative of Absolute Being, colour can also be representative of the different levels of Being. Consequently, the use of light and colour in art may be viewed as symbolic of matters, such as the Absolute Being, different stages of a Sufi's spiritual journey and levels of the soul. Every colour also has a psychological effect, and the artist's choice of colour is not accidental, but on logic. The specific colour is not merely chosen for aesthetic purposes beauty, but also for the mood the artist wants to create and his intended message, embedded in the nature of each colour.

\section{Calligraphy}

In Islamic art and civilisation, the art of calligraphy is considered as the most important and sacred art, as it derives its sanctity from the Quran. The importance and sanctity of the written word in Islam is also portrayed throughout the Quran; an example being in Chapter 96, Al- 'Alaq verse 1-2 God tells Prophet Muhammad;

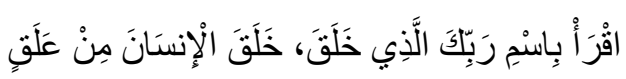

Recite! Thy Lord is most noble, Who taught by the Pen [6. 96:3-4].

Whilst Chapter 68, Al-Qalam starts with verses 1-2;

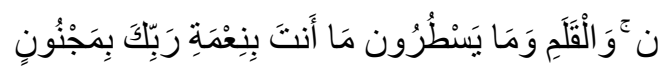

$N \bar{u} n$. By the pen and that which they inscribe, thou art not, by the blessing of thy Lord, possessed [6. 68: 1-2].

9 Creative Commons Attribution License. Nasir al-Mulk Mosque. Wikimedia. https://commons.wikimedia.org/wiki/File:Nasir_al-Mulk_Mosque_-_panoramio_(1).jpg\#/media/ File:Nasir_al-Mulk_Mosque_-_panoramio_(1).jpg. 
The imageries used in the Quran for the pen and the inkpot gave the necessary tools to Islamic scholars and Sufis for their various interpretations. Sufis, including 'Eynulqhużāt Hamidāni, Shaykh Rūzbahān Baqlī, and Maybudī, believed that the Arabic letters carry a hidden meaning. The disjointed alphabets (also known as hurüf-i muqatta $i$ ) found at the start of twenty-nine chapters of the Quran, comprising of seventy-eight characters (fourteen characters without repetition) in total, motivated these sufis to produce extensive explanations for such letterings and the Divine word of God [18. P. 411].

"In Christian decorative arts, images and paintings depicting religious imagery, often derived from the bible, play a significant role, not only in setting the tone of the architecture, but also in narrating a story, which sets the mood and theme of the building. We can refer to the Sistine Chapel's ceiling's artwork, as an example, which has the overall theme of salvation, and many of its scenes are derived from the Book of Genesis. in Islamic art, the text plays a similar function in architecture and decorative arts and is used to set the tone, mood, and context of the site, although this function is actualised through calligraphy and inscriptions rather than paintings.

The Quran is the manifestation of the speech of God, which takes the written form in the Quran, and is further transferred and manifested into the physical world by being inscribed on architectural monuments, adding a further element of sanctity to the monument." [7. P. 30] One of the earliest examples of the inscription of a calligraphic text with a purpose and to depict a set of beliefs are the inscriptions decorating the Dome of the Rock in Jerusalem. The inscriptions deal with the view of Jesus as the Messenger of God, rather than His son. The inscriptions were chosen due to the context of Dome of the Rock in Islamic, Christian and Jewish belief and in relation to the city of Jerusalem.

The major Islamic calligraphies are kufic, naskh, thuluth, riqā', and nasta 'liq, which have been employed in the khānqāh and shrine ensemble of Shaykh Safì alDin Ardabīlì. Arabic and Persian calligraphy is written on a horizontal base line, and read from right to left, with the additions of vowels being positioned above and below the letterings in the Arabic language. As previously discussed, the importance of Islamic calligraphy lies in its association with the written word of God, and its ability to depict imagery.

Ibn Muqla, a vizier in the Abbasid caliphate, was the master calligrapher of the $9^{\text {th }} / 10^{\text {th }} \mathrm{CE}$. He introduced a system in which all scripts would be in proportion to one another. He also codified the six scripts of calligraphy (al-qalam al-sitta) known as naskh, thuluth, muhaqqaq, rīhānī, riqā and tauqī. Furthermore, Ibn Muqla standardised all cursive inscriptions, and, using dots or points and triangles, introduced a system in which all Arabic alphabets would be in proportion to one another [19. P. 15-16].

The first letter of the Arabic alphabet, alif (الف or I) is a vertical stroke, with its height being equivalent to the diameter of a circle or five, seven, or nine rhomboid 
points high, which encircles all the letters of the selected script. Therefore, the rhomboid point, the alif, and the circle are required for the correct proportional formation of the rest of the alphabets in a given script. The second letter of the Arabic alphabet, $b \bar{a}$ (B or $\varphi$ ), would follow the rhomboid points measurements introduced by Ibn Muqla and would be proportional to the height of the alif, following a system of proportion [20. P. 18].

One of the most significant attributes of the khānqāh and shrine ensemble of Sheikh Safi is the vast number of calligraphic inscriptions decorating the monument, which consist of verses of the Quran, ahādīth, Persian poetry and sheikh Safi al-Din's lineage. Various styles of calligraphy, such as kufic, thuluth, naskh, riqā, and nasta 'liq, have been incorporated, using different decorative materials. The artists have chosen specific passages based on the location on which they would be inscribed. An example being the two-lined calligraphic inscription of verses 18 19 of chapter 3, Ali 'Imran in gold kufic and white thuluth inscribed on the space linking the body of Allah Allah Dome (i.e. Shaykh Șafi al-Din's tomb tower built in1335-1350 CE) and the drum, which deals with the Oneness of God, and some of the other Attributes that arise from this. It can be argued that this location was chosen for the above mentioned inscriptions to attract the attention and eye of the devotees who came to visit the shrine ensemble. Another example is the inscription of the word 'Allah' 132 times in turquoise bannā' $\overline{1}$ kufic on the exterior of the tomb tower. The 'Allah' inscriptions on the exterior of the tomb tower are written horizontally and vertically and are one meter long, in order to be seen from a distance (figure 5). "The word 'Allah' is God's unique name, and according to Islamic Sufism all other names and attributes of God manifest from this word. Consequently, 'Allah' is the most holy word used in the Qur'an, which has been repeated 3,027 times, and, therefore, it is the main dhikr of the Safaviyya Sufi Order." [7. P. 34]

The importance of the written word in Islamic culture and its connection to the written word of God has flourished throughout the centuries. The importance of rhythm, proportion, and precision in Islamic calligraphy influenced and disciplined other artforms. Furthermore, it has been utilised in art and architecture to both aesthetically decorate and portrays a specific message to the observers. Thus, it is essential to analyse and interpret the reasons for the deployment of calligraphic inscriptions in relation to the specific passages used, colours utilised, as well as their location for a better understanding of a given work of art.

\section{Conclusion}

The analysis and interpretation of Islamic art cannot solely be dependent on sociology of art and art history, but rather it must take into account the principles of Islamic philosophy and Sufism which were the pillars of the intellectual milieu in which a given work of art was produced. The commentary and interpretation of the doctrines of Imagination, colour and calligraphy doctrines are crucial, as they have been used in the creation of a work of art. Application of these principles to 
Islamic art creates the means for interpretation of the original concepts behind visual forms of art, and as such, facilitate a more comprehensive understanding of Islamic art.

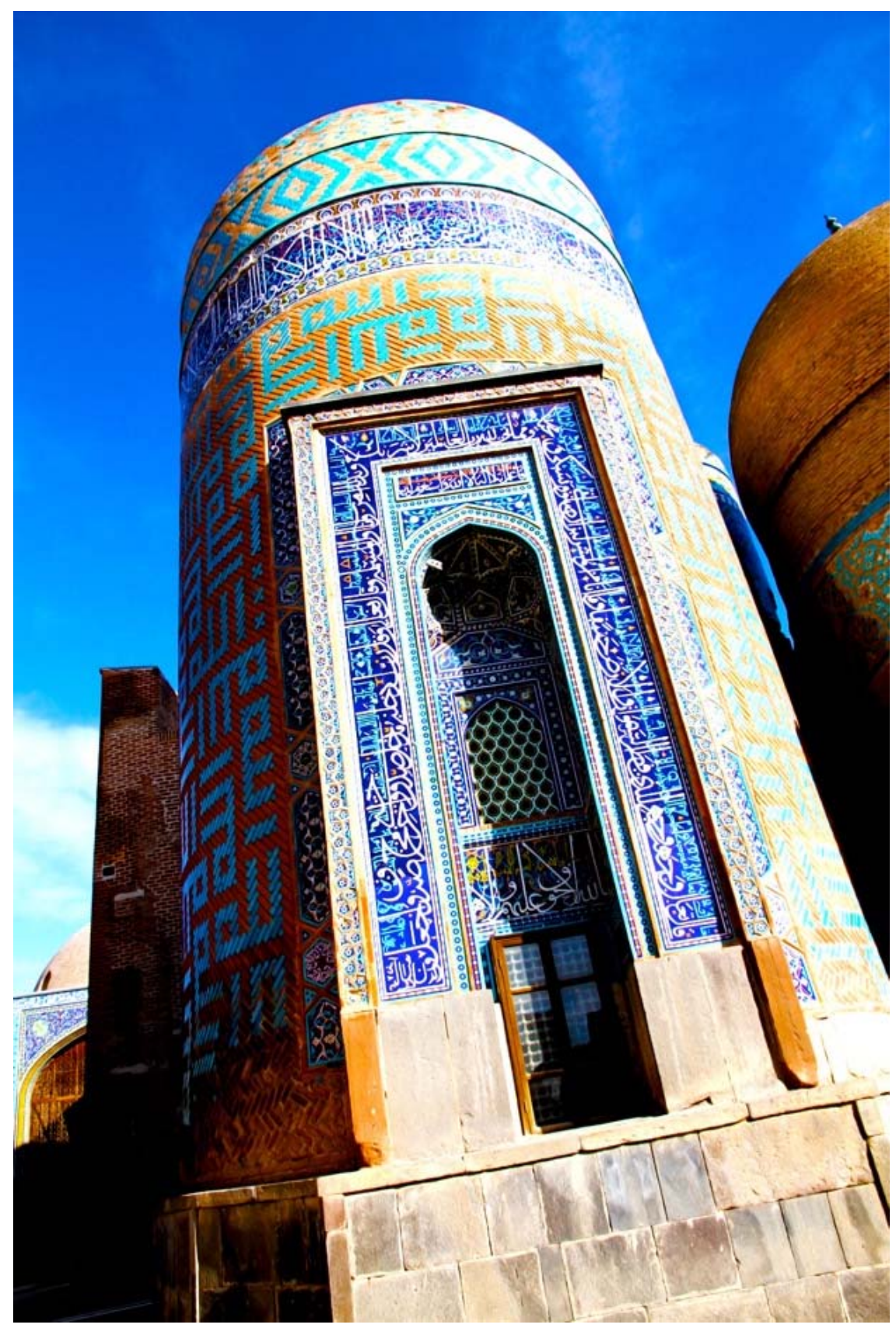

Figure 5. Allah Allah Dome - Shaykh Șafi al-Din Ardabīlī’s khānqāh and shrine ensemble - Ardabil, Iran ${ }^{10}$

\footnotetext{
${ }^{10}$ Photographer: Hasti Safavi, Copyright (C) Hasti Safavi
} 


\section{References}

[1] Ibn Sīnā. Tarjum-i va Sharḥ-i Ilāhiyātt-i Nijāt-i Shaykh al-Ra'is Abū Alī Sìnā. Y Yasribī, trans. Qum: Būstān-i Kitāb-i Qum; 1385 Sh/2006. (In Persian)

[2] M Quṭb al-Din Shīrāzī. Sharhh-i Hikmat al-Ishrāq Suhrawardī. A Nūrānī, M Muḥaqiq, eds. Tehrān: Anjoman-i Tārīkh va Mafāsir-i Farhangī; 1379 Sh/2000. (In Persian)

[3] D Qayșarī. Sharhh-i Fuṣūṣ al-Hikam. Vol 1. Tehrān: Intishārāt-i Mawlā; 1387 Sh/2008. (In Persian)

[4] Ibn 'Arabī. Fusūs al-Hikam. M Khājavī, trans. Tehrān: Mawlawī; 1393 Sh/2014. (In Persian)

[5] Ettinghausen R, Grabar O, Jenkins-Madina M. Islamic Art and Architecture 650-1250. New Haven and London: Yale University Press; 2001.

[6] The Study of Quran, SH Nasr, trans. New York: Harper Collins; 2015.

[7] Safavi H. Philosophy of Islamic Art and Architecture: Sheikh Safi al-Din Ardabili's Khanqah and Shrine Ensemble \& Gawharshad Mosque in Mashhad. London: London Academy of Iranian Studies Press; 2018.

[8] Kubrā N. Nasīm-i Jamāl va Dibāchi-yi Jalāl. Q Ansārī, trans. Tehrān: Tahūrī, 1388 $\mathrm{Sh} / 2009$. (In Persian).

[9] Rāzī N. Mirșād al-'Ibād min al-Mabda' ila al-Ma 'ād, $13^{\text {th }}$ Ed. Tehrān: Shirkat-i Intishārāti 'Ilmī va Farhangī; 1387 Sh/2008. (In Persian)

[10] A Simnānī. al-Orwa li-ahl al-khalwa va al-jelva, edited by N Māyil Hiravī. $2^{\text {nd }}$ Ed. Tehrān: Intishārāt-i Mawlā; 1395 Sh/2016. (In Persian)

[11] The Meaning of the Glorious Qur'an. Al-Baqarah: The Cow. Sacred Texts website. https://www.sacred-texts.com/isl/pick/002.htm. Accessed July $5^{\text {th }}, 2018$.

[12] Țabāṭabāyi MH. al-Mizān fi Tafsīr al-Qurān. Site Shahīd Āvīn̄. http://www.aviny.com/quran/almizan/jeld-1/mizan-11.aspx. Accessed July $5^{\text {th }}, 2018$. [In Persian].

[13] Qushayrī AQ. Lațā 'if al-Ishārāt. Cairo: al-Hiy’at al-Mișrī-ya al-Āmma lī al-Kitāb; 2000. (In Persian)

[14] Corbin H. Man of Light in Iranian Sufism. Nancy Pearson, trans. New York: Omega Publications Inc; 1994.

[15] Rumi MJ. The Mathnawi. RA Nicholson, trans. London: Luzac; 1971.

[16] Sabzivarī HM. Sharḥ-i Asrār-i Mathnawī Ma navī. Vol 1. Tehrān: Vizārat-i Farhang va Irshād-i Islāmī; 1371 Sh/1992. (In Persian)

[17] Lings M. Symbol \& Archetype: A Study of Meaning of Existence. Kentucky: Fons Vitae; 2006.

[18] Schimmel A. The Mystical Dimensions of Islam. Chapel Hill: The University of North Carolina Press; 1975.

[19] [Schimmel A, Rivolta B. Islamic Calligraphy. New York: Metropolitan Museum of Art; 1992.

[20] Schimmel A. Calligraphy and Islamic Culture. London: I.B. Tauris \& Co Ltd; 1990.

\footnotetext{
About the author:

Hasti Safavi - postgraduate student in the University of Exeter, graduate from the School of Oriental and African Studies of the University of London (e-mail: hasti.s@gmail.com).
} 


\title{
Исследование философских принципов исламского искусства
}

\author{
Хасти Сафави \\ Эксетерский университет \\ Stocker Road, Exeter, United Kingdom, EX4 4PY
}

\begin{abstract}
В западном академическом дискурсе принято рассматривать исламское искусство через призму истории искусства и социологии искусства. Исламское искусство воспринимается как сакральное для исламской культуры и цивилизации. Его священность выводится из Корана, эманируя из него, как из фонтана. Из Корана, который мусульмане считают Словом Божьим, подобно тому, как в христианстве Христос есть божественное Слово. Коран стал формообразующим фактором в возникновении триады сакрального исламского искусства: рецитация Корана, каллиграфия и архитектура. Однако возможен и другой подход, который не только жизнеспособен, но и может иметь большое значение для изучения исламского искусства. Этот подход заключается в том, чтобы задействовать принципы исламской философии и суфизма, которые легли в основание исследуемого предмета искусства. В данной статье мы рассмотрим концепции воображения, света и каллиграфии как учения, имеющие принципиальное значение для ислама и суфизма, а также приведем примеры их использования в ханаке и архитектурном ансамбле мавзолея Шейха Сафи ад-Дина Ардабили (Ардебиль, Иран).

Ключевые слова: Исламское искусство, философия, суфизм, Коран, воображение, цвет, каллиграфия, архитектурный ансамбль мавзолея Шейха Сафи ад-Дина Ардабили
\end{abstract}

\section{История статьи:}

Статья поступила 03.10.2019

Статья принята к публикации 06.11.2020

Для цитирования: Хасти Сафави. Исследование философских принципов исламского искусства // Вестник Российского университета дружбы народов. Серия: Философия. 2020. T. 24. No 1. C. 23-38. DOI: 10.22363/2313-2302-2020-24-1-23-38

\section{Сведения об авторе:}

Хасти Сафави - аспирантка Эксетерского университета, выпускница Школы востоковедения и африканистики Лондонского университета (e-mail: hasti.s@gmail.com). 